\title{
Microaspiration of Solanum tuberosum root cells at early stages of infection by Globodera pallida
}

\author{
Rinu Kooliyottil, Louise-Marie Dandurand* ${ }^{*}$, Joseph C. Kuhl, Allan Caplan and Fangming Xiao
}

\begin{abstract}
Background: Sedentary endoparasitic cyst nematodes form a feeding structure in plant roots, called a syncytium. Syncytium formation involves extensive transcriptional modifications, which leads to cell modifications such as increased cytoplasmic streaming, enlarged nuclei, increased numbers of organelles, and replacement of a central vacuole by many small vacuoles. When whole root RNA is isolated and analyzed, transcript changes manifested in the infected plant cells are overshadowed by gene expression from cells of the entire root system. Use of microaspiration allows isolation of the content of nematode infected cells from a heterogeneous cell population. However, one challenge with this method is identifying the nematode infected cells under the microscope at early stages of infection. This problem was addressed by staining nematode juveniles with a fluorescent dye prior to infection so that the infected cells could be located and microaspirated.

Results: In the present study, we used the fluorescent vital stain PKH26 coupled with a micro-rhizosphere chamber to locate the infected nematode Globodera pallida in Solanum tuberosum root cells. This enabled microaspiration of nematode-infected root cells during the early stages of parasitism. To study the transcriptional events occurring in these cells, an RNA isolation method from microaspirated samples was optimized, and subsequently the RNA was purified using magnetic beads. With this method, we obtained an RNA quality number of 7.8. For transcriptome studies, cDNA was synthesized from the isolated RNA and assessed by successfully amplifying several pathogenesis related protein coding genes.

Conclusion: The use of PKH26 stained nematode juveniles enabled early detection of nematode infected cells for microaspiration. To investigate transcriptional changes in low yielding RNA samples, bead-based RNA extraction procedures minimized RNA degradation and provided high quality RNA. This protocol provides a robust procedure to analyze gene expression in nematode-infected cells.
\end{abstract}

Keywords: Plant parasitic nematode, Feeding site, Microaspiration, Transcriptome, Pathogenesis related genes

\section{Background}

Globodera pallida (Stone) Behrens (pale cyst nematode, $\mathrm{PCN}$ ) is a sedentary endoparasitic nematode that causes severe yield loss of potatoes (Solanum tuberosum L.). Infective second stage juveniles (J2s) of G. pallida invade the roots of the host plant and establish a feeding site by fusing several cells into a single syncytium $[10,15,22$, 28]. The nematode secretes a cocktail of proteins called

*Correspondence: Imd@uidaho.edu

Department of Plant Soil and Entomological Sciences, University of Idaho, Moscow, ID 83844, USA effectors which are responsible for altering the cellular machinery of susceptible plants leading to the formation of the syncytium $[6,16]$. Understanding how host gene expression changes after G. pallida infection is important for the development of resistance as is needed for potato including russet-type varieties.

Genes upregulated in nematode infected plants have been classified into primary (genes induced up to 1-day post infection) or secondary upregulated genes (genes induced after 3-days infection) [25]. Primary upregulated genes may be involved in wounding, pathogen 
recognition, and syncytium initiation, whereas, many of the genes induced later have been associated with syncytial development and maintenance. Genes responding to stress or pathogen defenses, involved in the cell cycle, or associated with the cytoskeleton fall into both categories [25]. Swiecicka et al. [25] reported $20 \%$ greater expression of genes associated with phytohormone responses in the primary category compared to the secondary category in Globodera rostochiensis-infected Solanum lycopersicum. On the other hand, Ithal et al. [7] found a significantly higher expression of genes related to defense responses 2-5 days after Glycine max roots were infected by Heterodera glycines. In a recent study, we have reported localized cell death as early as 2 days post infection in Solanum sisymbriifolium roots [14]. In the present study, we developed a methodology to study cell-specific transcription in potato roots during early G. pallida infection stages.

In recent years, several investigators have conducted gene expression studies from nematode infected roots $[2,12,15]$. In most of these experiments, total RNA was isolated from the entire root system of an infected plant. The nematode infected plant cells are only a small fraction of the total root material, and as a result, changes in expression in a few cells at the site of infection are likely to be overshadowed by potentially less relevant changes induced throughout the root. In order to identify changes in gene expression occurring only in the nematodeinfected plant cells, many researchers collect cellular materials from infected cells using either laser capture microdissection (LCM) $[1,9,19]$ or microaspiration $[26$, 29]. Ramsay et al. [19] used LCM to study the expression of cell cycle genes in the cytoplasm of giant cells isolated from tomato roots infected with the root knot nematode Meloidogyne javanica 4 days post infection. Anjam et al. [1] successfully standardized a method for LCM sample processing for transcriptome analysis of Arabidopsis roots infected by Heterodera schachtii and compared pathogenesis related gene expression in 5-day-old syncytial cells to uninfected cells using qPCR.

At early stages of infection, nematode infected plant cells are structurally similar to other cells in the root system which makes them difficult to differentiate using microscopy techniques. To alleviate difficulties in recognition of infected tissue, many investigations on cell specific transcriptome analyses of nematode infected plant cells have been performed on tissues in later stages of parasitism when cells are morphologically distinguishable. For instance, to investigate the differential expression of several pathogenesis related genes, Wang et al. [29] microaspirated giant cells formed by M. javanica in tomato roots 25 days post infestation. For studies of 5 day old H. schachtii infected Arabidopsis cells, Szakasits et al.
[26] found a clear difference in gene expression between syncytia and other root cells using microaspiration. In the present study, our effort was to develop a methodology to locate the nematode inside the plant roots at early stages of parasitism during the initiation of a syncytium, and to isolate the content of these cells for RNA isolation. PKH26, a red fluorescent cell linker that binds to cell membrane lipids has been used for observation of plant parasitic nematodes when infecting plant roots $[4,14$, 24]. In the present study, we have used this dye to select nematode-infected cells in S. tuberosum roots that were grown in micro-rhizosphere chambers (micro-ROCs). In addition, a protocol was optimized for RNA isolation from microaspirated samples and utilized for downstream applications such as qPCR analyses.

\section{Results}

\section{PKH26 fluorescent labelling coupled with micro-ROCs} for microaspiration of Globodera pallida infected plant cells To investigate the cell specific transcriptome of nematode infected plant cells at early stages of infection, we developed a non-destructive microaspiration method. Plants were grown in micro-ROCs, which allows nondestructive detection and observation of nematodes within plant roots [14]. To prevent movement, desiccation and wounding of the root samples while microapsirating, plants were transferred from the micro-ROC to a glass slide lined with agarose.

In the past, locating infected plant cells to study cellular content has been difficult because detection methods were not available. To facilitate this process, hatched J2s were stained with PKH26 prior to inoculation on their host. With a rhodamine filter (dye excitation max. $551 \mathrm{~nm}$ and emission max. 567), PKH26 stained nematodes fluoresce red, and their movement and position was easily observed. To microaspirate cell content both nematode and plant cells need to be visualized at the the same time. To achieve this, brightfield was turned to a low setting which allowed visualization of the plant cell while also maintaining the fluorescence to visualize the site of the nematode within the plant root (Fig. 1). In Fig. 1c and the nematode is yellow due to the bright field illumination of the microscope which was turned on to enable visualization of the capillary needle for microaspiration. An image of PKH26 stained G. pallida with the rhodamine filter (in the absence of bright field illumination) has been inserted in Fig. 1c. Under these conditions, the capillary needle was visible and could be directed to the cells infected by the nematode. Until we filled the capillary needle with RNA extraction buffer (ARCTURUS ${ }^{\circledR}$ PicoPure ${ }^{\circledR}$ RNA isolation kit) to prevent RNA degradation, our early efforts resulted in degradation of the microaspirated RNA. Fragment analysis 
a

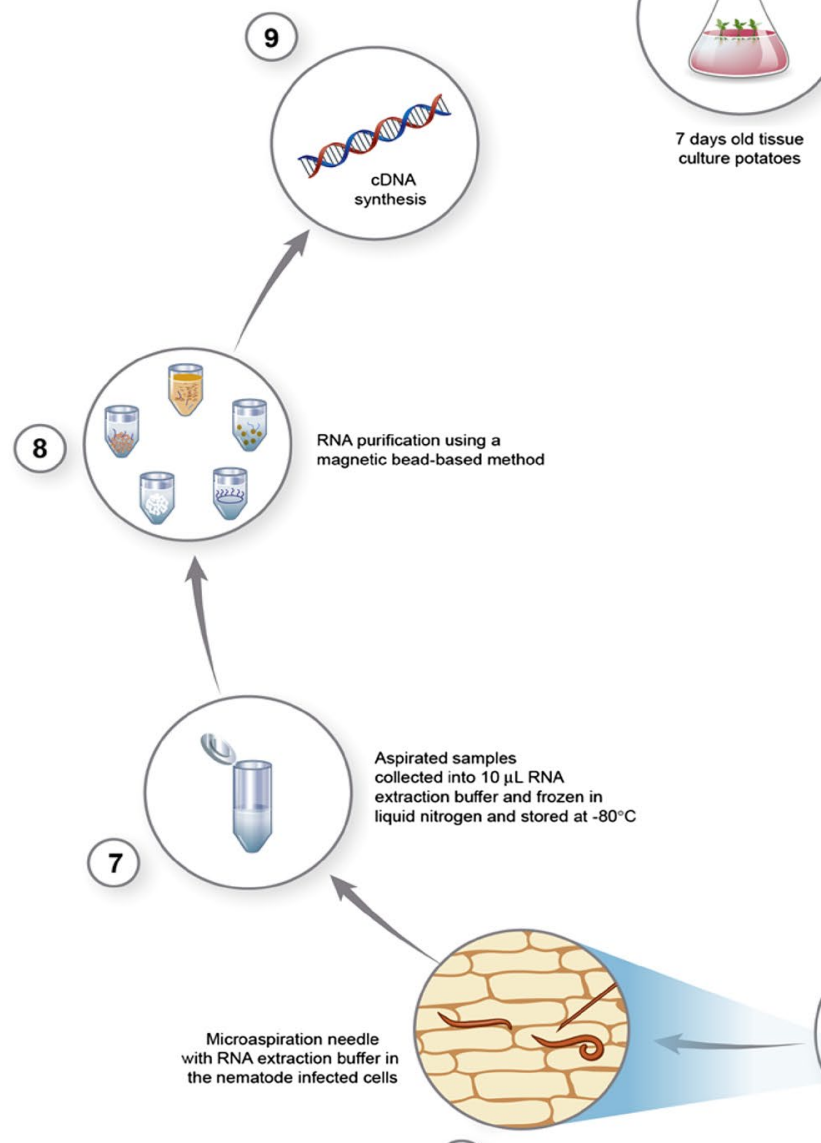

(6)
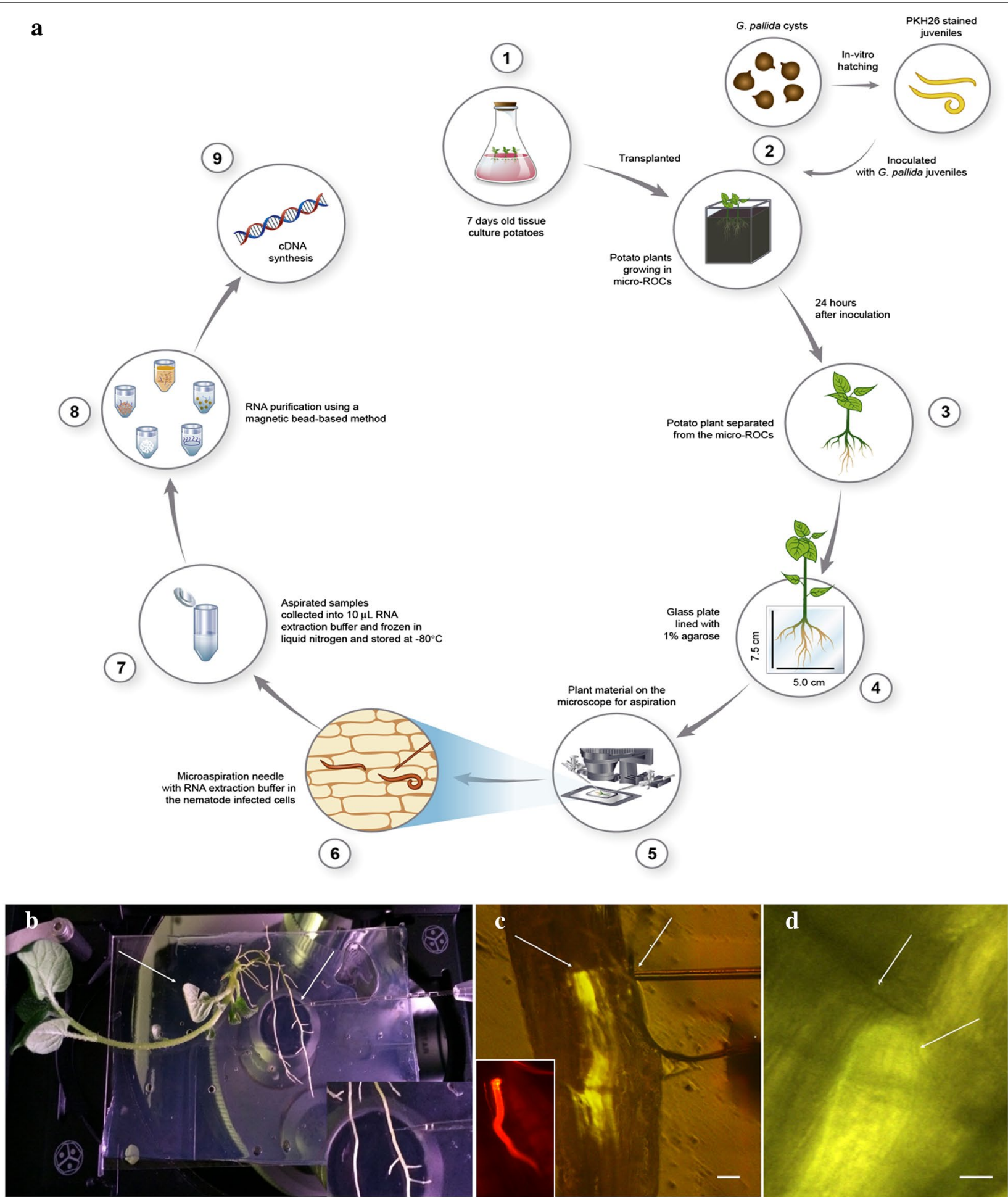

Fig. 1 Process of microaspiration and RNA isolation from Globodera pallida infected Solanum tuberosum root cells. a Schematic diagram of the workflow of nematode inoculation, microaspiration of infected cells and RNA isolation. b . tuberosum on a glass plate $(7.5 \mathrm{~cm} \mathrm{~L} \times 5.0 \mathrm{~cm} \mathrm{~W})$ ready for microaspiration, the left arrow shows the glass plate lined with agarose; right arrow shows the needle and the root; the inset is of a close view of the root perforated by the capillary needle. $\mathbf{c}$ PKH26 stained G. pallida located under a fluorescent microscope with capillary needle inside the root cell; the bright field illumination was turned on to a low setting to allow the capillary needle to be seen; the inset shows the image of G. pallida through a rhodamine filter without bright field illumination; the left arrow indicates the head region of the nematode; right arrow shows the root perforated by the capillary needle. $\mathbf{d}$ The head region of G. pallida (lower arrow) inside the root cell with the aspirator needle (upper arrow). The needle contains extraction buffer to prevent RNA degradation. Bar $=20 \mu \mathrm{M}$ 
revealed higher levels of RNA once the capillary needle was filled with buffer prior to aspiration of cell content.

\section{Standardization of RNA isolation protocol from microaspirated plant cells}

Wounding of plant cells causes expression of woundinducible genes. To minimize wounding effect from the root samples, only one sample was aspirated from each root. Initially, the quality and quantity of RNA extracted and purified from this small amount of sample using the ARCTURUS ${ }^{\circledR}$ PicoPure ${ }^{\circledR}$ RNA isolation kit protocol was not adequate for further downstream processes (Fig. 2). To increase the purity and quality of RNA from the microaspirated samples, we modified the ARCTURUS ${ }^{\circledR}$ PicoPure ${ }^{\circledR}$ RNA isolation kit protocol by reducing the initial incubation time from the suggested $30 \mathrm{~min}$ by $5 \mathrm{~min}$ increments from 0 to $20 \mathrm{~min}$. Incubating the sample for 15 min provided the highest quality RNA, with the RNA Quality Number (RQN) of 4.0 and the total concentration of $0.85 \mathrm{ng} / \mu \mathrm{L}$ (Fig. 2). To further improve the quality of RNA, the sample was further processed by using a magnetic bead-based protocol. This method yielded $12.8 \mathrm{ng}$ RNA with an RQN of 7.8 dissolved in $10 \mu \mathrm{l}$ (Fig. 2), or a total of $12.8 \mathrm{ng}$ per aspirated sample.

\section{Amplification of genes from Globodera pallida infected Solanum tuberosum cells}

To test the downstream applications of the RNA isolated from nematode-infected plant cells, cDNA was synthesized, and one housekeeping gene, elongation factor, and 4 pathogenesis related (PR) genes (genes contributing to disease resistance), NADH-quinone oxidoreductase subunit C, CHTB4 (Chitinase), cinnamyl alcohol dehydrogenase, and 6-phosphogluconate dehydrogenase, were amplified using specific primers (Table 1). The PR genes were selected randomly from our RNAseq data (data not shown).

All genes were successfully amplified from the microaspirated cDNA derived samples and clear bands were observed on the electrophoresis gel (Fig. 3). Nematode infected plant cells were compared with non-infected cells for gene expression. qPCR analysis of the CHTB4 gene from cDNA 3 independent pairs of infected and uninfected samples showed 1.15 times higher expression of CHTB4 in infected cells compared to uninfected cells $24 \mathrm{~h}$ post infestation [cycle threshold $(\mathrm{Ct})$ of CHTB4 in infected cell cDNA $=23.76 \pm 0.04$, Ct of CHTB4 in control cell cDNA $=23.66 \pm 0.02$, Ct of elongation factor in infected cell cDNA $=21.35 \pm 0.03$, and Ct of elongation factor in control cell cDNA $=21.04 \pm 0.04]$. This indicates that RNA isolated from the micro aspirated samples can be utilized for transcriptome analysis of nematode infected plants. RNAseq libraries were also prepared from the RNA isolated in this study but the comparative transcriptomics results will be presented elsewhere.

\section{Discussion}

Cell specific transcriptome analysis using microaspiration and LCM have been successfully used to isolate cellular materials from the syncytium for plant-nematode interaction studies $[1,9,18]$. Tissue samples for transcriptome analysis obtained by LCM need to be fixed prior to sectioning and mounting $[1,3]$, which can cause RNA degradation.

Despite being an inexpensive technique compared to LCM, microaspiration is laborious for obtaining sufficient amounts of input sample for RNA isolation [1], and can only be performed once the syncytium is morphologically distinct. To overcome these limitations, we standardized a microaspiration method for early detection of infection sites, by staining the nematodes using a fluorescent stain, modifying incubation time and by using a bead-based RNA purification protocol. With these modifications, we obtained high quality RNA from low input samples for transcriptome analyses.

Recent studies using microscopy assisted techniques are conducted, in most cases 5 days or later after infection $[1,9,11,19,26,29]$. The main constraint in isolating cells of interest at early stages is in visualizing the nematode and the nematode infected plant cells prior to morphological changes caused by formation of the syncytium which is typically $4-5$ days post infection. The present study reports an improved microaspiration method for early stages of infection.

To study the nematode-plant interaction, we used PKH26 coupled with micro-ROCs $[4,14]$, which allows observation of live nematode inside the plant roots. The plants grown in micro-ROCs were removed with minimal damage to roots. To prevent slipping of the samples and desiccation or wounding of the roots, we used a glass plate layered with agarose. Wounding induces defense proteins $[5,21]$. To reduce these effects, we aspirated the contents of one cell from each root system. To obtain sufficient RNA, others, such as Juergensen et al. [11], aspirated 100 nematode infected cells from each root system for transcriptome analysis.

After aspirating the cell contents from infected cells, we attempted several methods to isolate pure RNA from this sample. Although, the ARCTURUS ${ }^{\circledR}$ PicoPure $^{\circledR}$ RNA isolation kit has been used for isolation of RNA from low yielding samples $[1,8,19]$, no mention of RNA quality obtained from these sample was made. Anjam et al. [1] standardized the LCM sample fixation protocol and reported the RNA integrity number of 7.8 using the ARCTURUS ${ }^{\circledR}$ PicoPure ${ }^{\circledR}$ RNA isolation kit. Despite several attempts using the manufacture's protocol for 


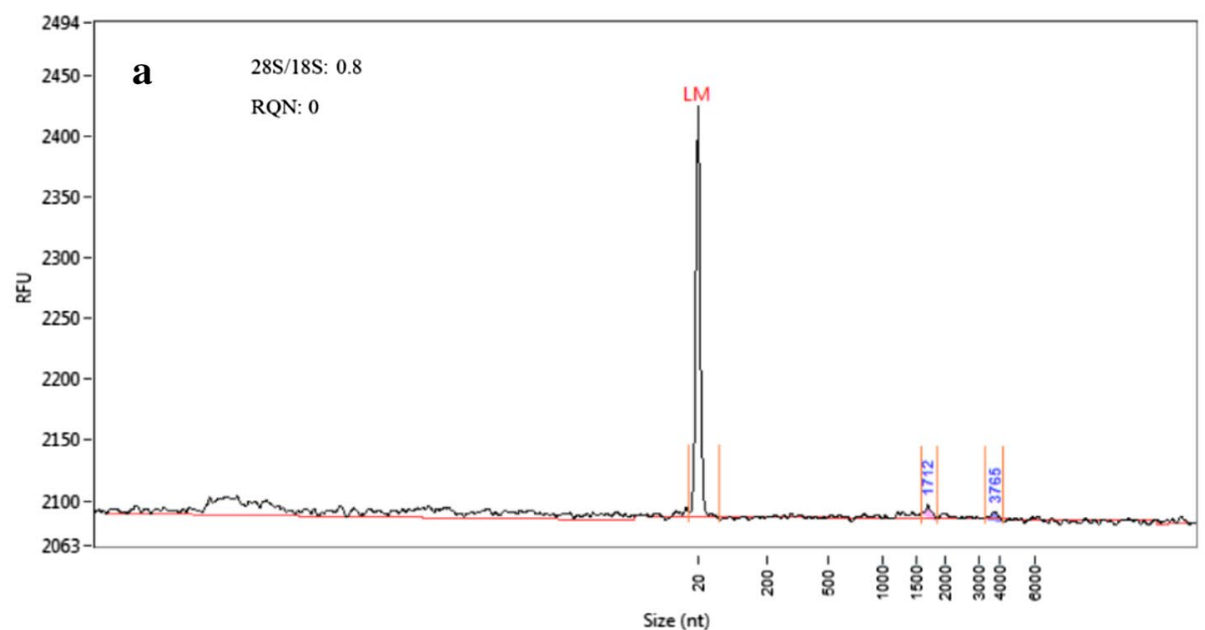

8000

4000

2000

1500

1000

500

200

20

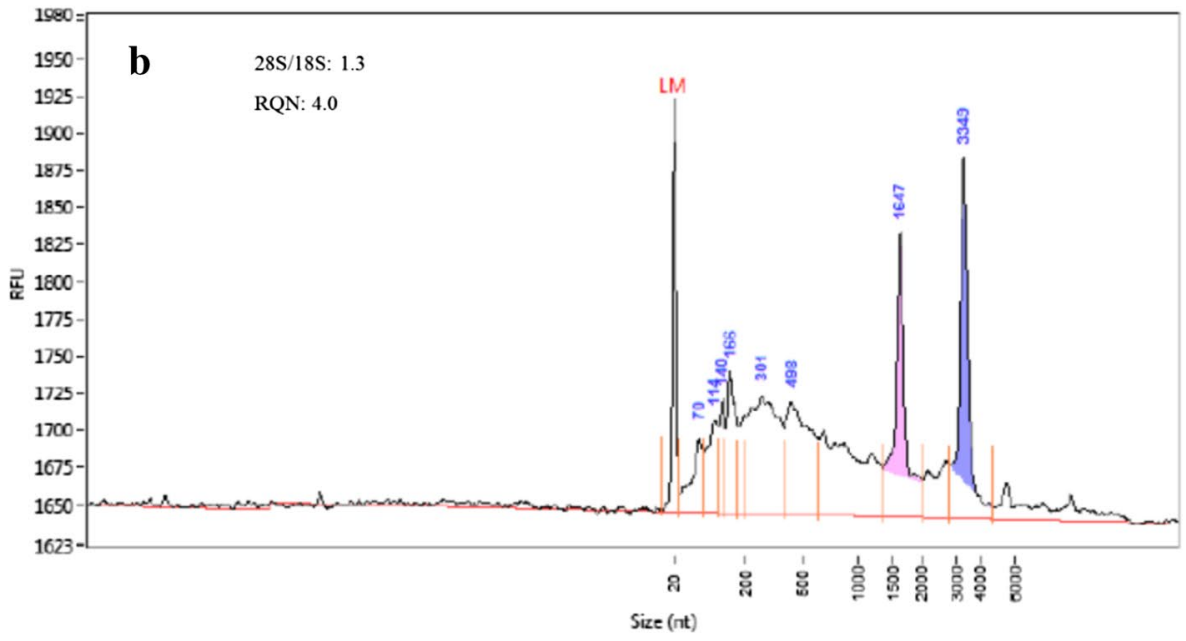

9000

4000

3000

2000

1500

1000

900

200

20
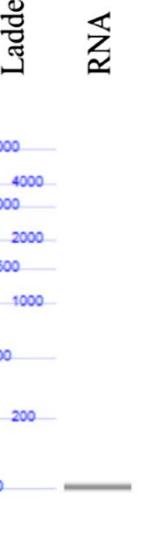
Table 1 Primer sequences used for amplification of cDNA samples synthesized from RNA isolated from microaspirated Globodera pallida infected and un-infected potato roots cells

\begin{tabular}{|c|c|c|c|}
\hline Gene & Primer sequence $\left(5^{\prime}-3^{\prime}\right)$ & Product size (bp) & Genbank accession number \\
\hline Elongation factor & $\begin{array}{l}\text { Forward AACCGCTGAGAACTTCCGAG } \\
\text { Reverse CGACCCAACAAGACACAAGC }\end{array}$ & 566 & AJ536671.1 \\
\hline Cinnamyl alcohol dehydrogenase & $\begin{array}{l}\text { Forward TGCACATAACAGGGGAGCTG } \\
\text { Reverse ATTACAGAGGCGCAACCAGG }\end{array}$ & 579 & JQ619511.1 \\
\hline 6-Phosphogluconate dehydrogenase & $\begin{array}{l}\text { Forward TTGGTGGGAGGTTTCTCGTG } \\
\text { Reverse CCTGCCAATTTGGTTCAGGC }\end{array}$ & 502 & XM_006363489.2 \\
\hline NADH-quinone oxidoreductase subunit C & $\begin{array}{l}\text { Forward CCAAGACTAAGGCCGAGCAA } \\
\text { Reverse GGACGGATCACCTGTCGATC }\end{array}$ & 520 & AY056140.1 \\
\hline CHTB4 (Chitinase) & $\begin{array}{l}\text { Forward CTGTTGCAGCAATTTCGGCT } \\
\text { Reverse AAATTTGGATGGGGCCTCGT }\end{array}$ & 576 & U02608.1 \\
\hline
\end{tabular}

Except for elongation factor, all primers were designed using gene sequences from RNAseq data. Therefore, the Genbank accession numbers given here are of identical sequences found in the NCBI

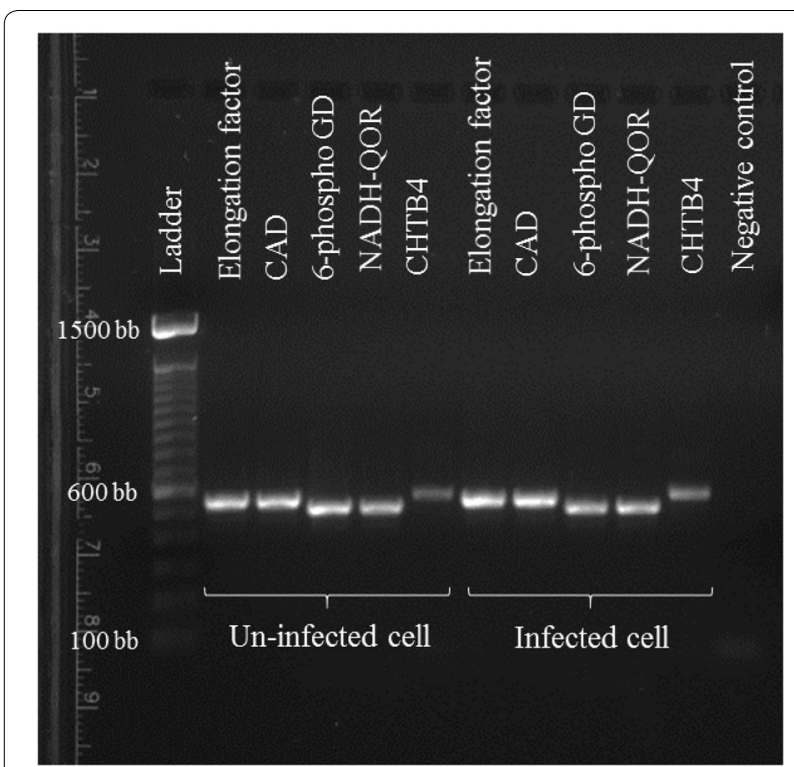

Fig. 3 PCR Analysis of housekeeping (elongation factor) and pathogenesis related (CAD Cinnamyl alcohol dehydrogenase, 6-phospho GD 6-phosphogluconate dehydrogenase, NADH-QOR $\mathrm{NADH}$-quinone oxidoreductase subunit C, CHTB4 Chitinase) genes in Globodera pallida infected and uninfected root cells of potato. Ladder is $100-1500 \mathrm{bp}$

the ARCTURUS ${ }^{\circledR}$ PicoPure ${ }^{\circledR}$ RNA isolation kit we did not get sufficient amounts or quality of RNA for downstream applications. However, when we reduced the incubation time from the initial 30 to $15 \mathrm{~min}$ an RQN of 4.0 was obtained. Most of the commercially available kits use column separation methods, which, in our experiments, did not yield high quality RNA for downstream applications such as RNAseq. In order to obtain RNA of adequate quality, we replaced columns with magnetic beads (Agencourt RNAdvance Tissue total RNA extraction kit) and were able to obtain RQN values of 7.8. Karrer et al. [13] used oligo (dT)-linked magnetic beads for cDNA synthesis directly from aspirated samples. In magnetic bead-based protocols, nucleic acids present in the solution are first bound to a magnetic carrier that have immobilized affinity ligands and then washed with a buffer to remove contaminants, and finally eluted using nuclease free water [27]. In our study, this method gave promising quantities and improved the quality of RNA from low amounts of input material.

To evaluate whether the RNA we obtained could be used for downstream applications, the isolated RNA was converted into cDNA and used for RNAseq and qPCR. Elongation factor and PR protein coding genes were amplified from these cDNA samples. qPCR was also successfully conducted for gene expression analysis from infected and non-infected cells of the same plant. RNAseq libraries were also prepared from this study and the results will be published elsewhere.

\section{Conclusion}

Because of the ability to study a single cell-type from a heterogeneous population, cell specific transcriptome analysis has become increasingly popular in animal, human and plant systems. Sedentary endoparasitic nematodes, such as cyst and root knot nematodes, form a feeding structure in the vascular tissues of the plant roots, and these tissues are metabolically different from other plant tissues due to the interaction between the host and the pathogen. It is crucial to understand the nematode-plant interaction at early stages of infection because early responses that may be suppressed in later stages, may be important for parasitism and host defense. PKH26 stained juveniles were used to locate infected sites for microaspiration. The RNA quality was improved significantly by adjusting the incubation time of the 
ARCTURUS ${ }^{\circledR}$ PicoPure ${ }^{\circledR}$ RNA isolation kit and by using a bead-based RNA purification kit (Agencourt RNAdvance Tissue total RNA extraction kit). As evidenced by qPCR of genes from infected and non-infected material, this RNA was of sufficient quality for gene expression studies. The approach presented here will provide suitable methods for early parasitism studies in nematodeplant interactions at the cellular level.

\section{Methods}

\section{Plant material and nematode inoculum}

Planting, nematode inoculum preparation and inoculation were performed as described in Kooliyottil et al. [14]. In brief, 1-week old Solanum tuberosum cv. 'Desiree' grown in the tissue culture medium was transplanted into micro-ROCs and kept under greenhouse conditions $\left(18 \pm 2{ }^{\circ} \mathrm{C}, 16 \mathrm{~h}\right.$ light and $8 \mathrm{~h}$ dark cycle). Globodera pallida encysted eggs were hatched in potato root diffusate. The hatched second stage juveniles (J2s) were surface sterilized and stained using PKH26 (Sigma Aldrich, USA) as per the manufaturer's protocol, and then suspended in $0.01 \%$ sterile agarose. Two weeks after planting in microROCs, pproximately 200 J2s suspended in agarose were inoculated onto the roots of S. tuberosum $[4,14]$.

\section{Microaspiration of G. pallida infected cells}

Twenty-four hours after inoculation, the plant was carefully removed from the micro-ROCs by breaking the glass plate and gently washing the roots with sterile water for $15 \mathrm{~s}$. The plant was then placed on to a glass plate $(7.5 \mathrm{~cm} \mathrm{~L} \times 5.0 \mathrm{~cm} \mathrm{~W})$ previously lined with $1 \%$ agarose (Fig. 1a). Infected roots were observed with a fluorescent microscope (DMI 3000B, Leica, Germany) and fluorescing G. pallida J2s were located within the root by use of a rhodamine filter under low magnification (20X objective lens).

To aspirate cell content, the capillary needle (TransferTip $^{\circledR}-\mathrm{R}$ ICIS, inner diameter $4 \mu \mathrm{M}$, outer diameter $7 \mu \mathrm{M}$, tip angle $35^{\circ}$, Eppendorf, Hamburg, Germany) of the micro manipulator (CellTram ${ }^{\circledR}$ vario, Eppendorf, Hamburg, Germany) filled with RNA extraction buffer (ARCTURUS PicoPure RNA Isolation Kit, Life Technologies, USA) was used to pierce the plant root with assistance from TransferMan ${ }^{\circledR}$ (Eppendorf, Hamburg, Germany). While entering the root, the CellTram ${ }^{\circledR}$ vario was turned to the injection mode to avoid the entry of any unwanted plant cell material into the needle due to the turgor pressure of the plant cell. Once the infected cell was reached, the CellTram ${ }^{\circledR}$ vario was turned to the aspiration mode to aspirate plant cellular material. The microaspirate contents were immediately transferred to $10 \mu \mathrm{L}$ RNA extraction buffer provided in the ARCTURUS PicoPure RNA Isolation Kit (Life Technologies,
USA), frozen in liquid nitrogen, and stored at $-80{ }^{\circ} \mathrm{C}$. Cell content of uninfected cells from the infected roots were also aspirated for gene expression comparison.

\section{RNA isolation from microaspirated plant material, CDNA synthesis and gene amplification}

Initial attempts to isolate total RNA from the microaspirated cell content were conducted by using the manufacture's protocol from ARCTURUS PicoPure RNA Isolation Kit (Life Technologies, USA). Frozen microaspirated samples were thawed by incubating at $42{ }^{\circ} \mathrm{C}$ for $30 \mathrm{~min}$. However, the quality of RNA extracted in this way was not sufficient for further analysis despite several attempts. Reduction in the initial incubation time was attempted by first using $30 \mathrm{~min}$ (as recommended manufacture's protocol), and then at intervals of 5 min from 0 to $20 \mathrm{~min} ; 15 \mathrm{~min}$ interval provided the best quality RNA. However, to further improve the quality, samples were processed by using a magnetic bead-based method. In brief, the samples incubated at $42^{\circ} \mathrm{C}$ for $15 \mathrm{~min}$ (from the above mentioned protocol), were supplemented with the magnetic bead buffer provided in the Agencourt RNAdvance Tissue total RNA extraction kit (Beckman Coulter, USA) and further steps of magnetic separation and washing was performed as per the protocol provided by the manufacturer. To avoid any genomic DNA contamination in the RNA, each sample was treated with DNAse following the recommended protocol from the Agencourt RNAdvance Tissue total RNA extraction kit.

Qualitative and quantitative analysis of the purified RNA was determined by using a FRAGMENT ANALYZER $^{\mathrm{TM}}$ (Advanced Analytical Technologies Inc., USA). RNA was reverse-transcribed into cDNA according to the procedure described in the SUPERSCRIPT ${ }^{\circledR}$ II reverse transcriptase (Invitrogen) using oligo (dT) primer (Thermo Fisher Scientific Inc, MA, USA) and dNTP mix. The quality and quantity of cDNA was determined by using a NanoDrop ${ }^{\mathrm{TM}}$ 2000c instrument (Thermo Scientific Inc, MA, USA). The cDNA from infected and uninfected samples were amplified using conventional PCR, with a housekeeping gene specific primer for elongation factor, and pathogenesis related (PR) genes namely $\mathrm{NADH}$-quinone oxidoreductase subunit C, CHTB4 (Chitinase), and 6-phosphogluconate dehydrogenase $[17,20$, 23]. The PCR (C1000 ${ }^{\mathrm{TM}}$ Thermal Cycler, BIO-RAD, USA) conditions were as follows: Initial denaturation, $95^{\circ} \mathrm{C}$ for 3 min; denaturation, $95^{\circ} \mathrm{C}$ for $30 \mathrm{~s} ; 62^{\circ} \mathrm{C}$ for $30 \mathrm{~s} ; 72{ }^{\circ} \mathrm{C}$ for 1:30 min; total cycles 40 ; final extension, $72{ }^{\circ} \mathrm{C}$ for $5 \mathrm{~min}$. The specific primers used for the amplification are given in Table 1.

To confirm gene expression levels in microaspirated infected and uninfected cells, cDNA from both samples were analyzed for expression of CHTB4 using qPCR 
(ViiA $^{\mathrm{TM}} 7$ Real-Time PCR System, Applied Biosystems, USA). The reaction was prepared in a total of $20 \mu \mathrm{L}$ in which $10 \mu \mathrm{L}$ master mix (FAST SYBR ${ }^{\mathrm{TM}}$ Green Master Mix, Thermo Fisher Scientific Inc, MA, USA), $1 \mu \mathrm{L}$ template cDNA (10 ng), $150 \mathrm{nM}$ (primer efficiency $=102.30$, $\mathrm{R}^{2}=0.99$ ) each of forward and reverse primers of elongation factor and $100 \mathrm{nM}$ (primer efficiency $=103.85$, $\mathrm{R}^{2}=0.97$ ) each of forward and reverse primers of CHTB4, and nuclease free water was added. The PCR condition was as follows: $50{ }^{\circ} \mathrm{C}$ for $2 \mathrm{~min}, 95{ }^{\circ} \mathrm{C}$ for $10 \mathrm{~min}, 60^{\circ} \mathrm{C}$ for $1 \mathrm{~min}, 95^{\circ} \mathrm{C}$ for $15 \mathrm{~s} 15{ }^{\circ} \mathrm{C}$ for $1 \mathrm{~min}$ and $95{ }^{\circ} \mathrm{C}$ for $15 \mathrm{~s}$ with a total of 40 cycles. The relative expression level of CHTB4 was calculated in comparison to elongation factor by means of $2^{\text {(control sample Ct of tar- }}$ get-infected sample Ct of target) $\div 2^{\text {(control sample } \mathrm{Ct} \text { of reference-infected }}$ sample Ct of reference). The results presented are the average of three independent infections and sample collections.

\section{Authors' contributions}

RK performed experiments. RK and LMD designed the research and wrote the paper. JCK, AC and FX helped to design experiments and edited the manuscript. All authors read and approved the final manuscript.

\section{Acknowledgements}

The Institute for Bioinformatics and Evolutionary Studies (IBEST), University of Idaho for support with analytical instruments.

\section{Competing interests}

The authors declare that they have no competing interests.

\section{Availability of data and materials}

All data generated or analyzed during this study are available in this published article.

\section{Consent for publication \\ Not applicable.}

Ethics approval and consent to participate

Not applicable.

\section{Funding}

This research was funded by USDA-APHIS, Idaho Potato Commission and the Northwest Potato Research Consortium.

\section{Publisher's Note}

Springer Nature remains neutral with regard to jurisdictional claims in published maps and institutional affiliations.

Received: 5 May 2017 Accepted: 16 August 2017

Published online: 24 August 2017

\section{References}

1. Anjam MS, Ludwig Y, Hochholdinger F, Miyaura C, Inada M, Siddique S, Grundler FMW. An improved procedure for isolation of high-quality RNA from nematode-infected Arabidopsis roots through laser capture microdissection. Plant Methods. 2016;12(1):25. doi:10.1186/s13007-016-0123-9.

2. Bohlmann $H$, Sobczak M. The plant cell wall in the feeding sites of cyst nematode. Front Plant Sci. 2014;5:1-10.

3. Clément-Ziza M, Lyonnet S, Jaubert F, Besmond C. Stabilization of RNA during laser capture microdissection by performing experiments under argon atmosphere or using ethanol as a solvent in staining solutions. RNA. 2008;14:2698-704.
4. Dinh PTY, Knoblauch M, Elling AA. Nondestructive imaging of plantparasitic nematode development and host response to nematode pathogenesis. Phytopathology. 2014;104:497-506.

5. Graham JS, Hall G, Pearce G, Ryan CA. Regulation of synthesis of proteinase inhibitors I and II mRNAs in leaves of wounded tomato plants. Planta. 1986;69:399-405

6. Holbein J, Grundler FMW, Siddique S. Plant basal resistance to nematodes: an update. J Exp Bot. 2016;67:2049-61.

7. Ithal N, Recknor J, Nettleton D, Hearne L, Maier T, Baum TJ, Mitchum MG Parallel genome-wide expression profiling of host and pathogen during soybean cyst nematode infection of soybean. Mol Plant Microbe Interact. 2007;20:293-305

8. Ithal N, Recknor J, Nettleton D, Maier T, Baum TJ, Mitchum MG. Developmental transcript profiling of cyst nematode feeding cells in soybean roots. Mol Plant Microbe Interact. 2007;20:510-25.

9. Ji H, Gheysen G, Denil S, Lindsey K, Topping JF, Nahar K, Haegeman A, De Vos WH, Trooskens G, Criekinge WV, Meyer TD, Kyndt T. Transcriptional analysis through RNA sequencing of giant cells induced by Meloidogyne graminicola in rice roots. J Exp Bot. 2013;64:3885-98.

10. Jones MGK. Host cell responses to endoparasitic nematode attack: structure and function of giant cells and syncytia. Ann Appl Biol. 1981;97:353-72.

11. Juergensen K, Scholz-Starke J, Sauer N, Hess P, van Bel AJE, Grundler FMW. The companion cell-specific arabidopsis disaccharide carrier AtSUC2 is expressed in nematode-induced syncytia. Plant Physiol. 2003;131:61-9.

12. Kammerhofer N, Radakovic Z, Regis JMA, Dobrev P, Vankova R, Grundler FMW, Siddique S, Hofmann J, Wieczorek K. Role of stress hormones in plant defence during early infection of the cyst nematode Heterodera schachtii in Arabidopsis. New Phytol. 2015;207:778-89.

13. Karrer EE, Lincoln JE, Hogenhout S, Bennet AB, Bostock RM, Martineau B, Lucan WJ, Glichrist DG, Alexander D. In situ isolation of mRNA from individual plant cells: creation of cell-specific cDNA libraries. Proc Natl Acad Sci USA. 1995:92:3714-818

14. Kooliyottil R, Dandurand LM, Govindan BN, Knudsen GR. Microscopy method to compare cyst nematode infection of different plant species. Adv Biosci Biotechnol. 2016;7:311-8.

15. Kyndt T, Vieira P, Gheysen G, de Almedia-Engler J. Nematode feeding sites: unique organs in plant roots. Planta. 2013;238:807-18.

16. Lilley CJ, Atkinson HJ, Urwin PE. Molecular aspects of cyst nematodes. Mol Plant Pathol. 2005;6:577-88.

17. Noel GR, McClure MA. Peroxidase and 6-phosphogluconate dehydrogenase in resistant and susceptible cotton infected by Meloidogyne incognita. J Nematol. 1978;10:34-8.

18. Portillo M, Lindsey K, Casson S, García-Casado G, Solano R, Fenoll C, Escobar C. Isolation of RNA from laser-capture-microdissected giant cells at early differentiation stages suitable for differential transcriptome analysis. Mol Plant Pathol. 2009;10:523-35.

19. Ramsay K, Wang Z, Jones MGK. Using laser capture microdissection to study gene expression in early stages of giant cells induced by root-knot nematode. Mol Plant Pathol. 2004;5:587-92.

20. Ryan A, Kaplan E, Nebel JC, Polycarpou E, Crescente V, Lowe E, Preston $\mathrm{GM}$, Sim E. Identification of $\mathrm{NAD}(\mathrm{P}) \mathrm{H}$ quinone oxidoreductase activity in azoreductases from P. aeruginosa: Azoreductases and NAD(P)H quinone oxidoreductases belong to the same FMN-dependent superfamily of enzymes. PLoS ONE. 2004:9(6):e98551.

21. Ryan CA. Protease inhibitors in plants: genes for improving defenses against insects and pathogens. Annu Rev Phytopathol. 1990;28:245-9.

22. Siddique $\mathrm{S}$, Radakovic ZS, De La Torre CM, Chronis D, Novák O, Ramireddy E, Holbein J, Matera C, Hütten M, Gutbrod P, Anjam MS, Rozanska E, Habash S, Elashry A, Sobczak M, Kakimoto T, Strnad M, Schmülling T, Mitchum MG, Grundler MW. A parasitic nematode releases cytokinin that controls cell division and orchestrates feeding site formation in host plants. Proc Natl Acad Sci USA. 2015;112:12669-74.

23. Smith CM, Boyko EV. The molecular bases of plant resistance and defense responses to aphid feeding: current status. Entomol Exp Appl. 2006;122:1-16.

24. Sobczak M, Avrova A, Jupowicz J, Phillips MS, Ernst K, Kumar A. Characterization of susceptibility and resistance responses to potato cyst nematode (Globodera spp.) infection of tomato lines in the absence and presence of the broad-spectrum nematode resistance Hero gene. Mol Plant Microbe Interact. 2005;18:158-68. 
25. Swiecicka M, Filipecki M, Lont D, Vliet JV, Qin L, Goverse A, Bakker J, Helder J. Dynamics in the tomato root transcriptome on infection with the potato cyst nematode Globodera rostochiensis. Mol Plant Pathol. 2009;10:487-500

26. Szakasits D, Heinen P, Wieczorek K, Hofmann J, Wagner F, Kreil DP, Sykacek $\mathrm{P}$, Grundler FM, Bohlmann $\mathrm{H}$. The transcriptome of syncytia induced by the cyst nematode Heterodera schachtii in Arabidopsis roots. Plant J. 2009;57:771-84.
27. Tan SC, Yiap BC. DNA, RNA and proteins extraction: the past and the present. J Biomed Biotechnol. 2009. doi:10.1155/2009/574398,1-10.

28. Uehara T, Sugiyama S, Matsuura H, Arie T, Masuta C. Resistant and susceptible responses in tomato to cyst nematode are differentially regulated by salicylic acid. Plant Cell Physiol. 2010;51:1524-36.

29. Wang Z, Potter RH, Jones MGK. Differential display analysis of gene expression in the cytoplasm of giant cells induced in tomato roots by Meloidogyne javanica. Mol Plant Pathol. 2003;4:361-71.

\section{Submit your next manuscript to BioMed Central and we will help you at every step:}

- We accept pre-submission inquiries

- Our selector tool helps you to find the most relevant journal

- We provide round the clock customer support

- Convenient online submission

- Thorough peer review

- Inclusion in PubMed and all major indexing services

- Maximum visibility for your research

Submit your manuscript at

www.biomedcentral.com/submit 